\title{
THE PROBLEM OF UNPROFITABLE ACTIVITY OF ENTERPRISES IN UKRAINE
}

\author{
Ivan Demchenko', Olena latsukh ${ }^{2}$ \\ Tavria State Agrotechnological University, Ukraine
}

\begin{abstract}
The subject of the study. A successful economy does not allow the loss of its main component: enterprises in modern conditions. If the companies of the country do not receive anticipated financial results, the entire financial system becomes vulnerable. This article is focused on research of the problem of loss-making enterprises in Ukraine. It should be noted that the negative trend of a significant number of loss-making companies can be traced over a long period of time. The main reasons for Ukrainian producing companies' unsatisfactory financial results are described in this article. A hierarchy of factors that determine the financial security of enterprises is constructed. Research of dependence operating profitability of businesses from inflation is done on the basis of statistical data. The tendency in the production of industrial output is shown. Methods. The methods used by authors include correlation analysis, comparative analysis, a method of description, interpretation of statistical data, a method of observation. Scope. The main task of the research remains the demonstration of the problem of non-profit activity of Ukrainian enterprises and the allocation of key factors for the containment of economic growth. For this purpose, a study was made of the dynamics of financial results of subjects of entrepreneurial activity. The dependence of profit on operating activities of the economic sector and the rates of inflation of the national economy of Ukraine is presented. Conclusions. National business adapts to the transformation of the economy and, at the same time, overcomes the diversity of threats. Performed analysis showed that enterprises in Ukraine are strongly influenced by internal independent administrative measures factors. The shortage of financial resources and the complexity of attracting additional funds impede the further development of enterprises. However, the size of revenues and costs, and thus the final financial results will depend on the professionalism of company's management. The problem of increasing insolvency among Ukrainian companies is disclosed in this paper. Profit formation is possible only if one takes into account the role of the state, changes in external and internal demand and maintaining competitiveness. Key directions of financial stabilization and further business development in Ukraine depend on the ability of entities to maintain an acceptable level of their own financial security.
\end{abstract}

Key words: financial crisis, entities, development, entrepreneurial sector, financial results, financial security.

JEL Classification: G32, G33, M21

\section{Introduction}

The profitability of enterprises determines the character of the development of the Ukrainian economy as a whole. Profitable enterprises form income tax revenue and their business activity is maximal. The country needs a sufficient amount of financial resources due to the need for active reforms and maintaining defence capability. In addition, many contradictions and imbalances requiring settlement for the further development of the country there are in the Ukrainian economy.

The government aims to intensify economic growth and create conditions for the development of enterprises. However, maintaining a large number of loss-making enterprises leads to lower tax revenues and putting pressure on the budget. The tax on profits of the enterprise is not made upon receipt of losses over the lack of the object of taxation. This situation is contrary to the principle of obligatory of the tax system of Ukraine (Adonin, 2015). In most cases, loss-making enterprises have poor financial performance, low business activity. They are characterized by a decreasing of production and sales, as well as the slow pace of innovation $d$ evelopment.

Corresponding author:

${ }^{1}$ Department of Finance, Banking and Insurance, Tavria State Agrotechnological University.

E-mail: ivanvd@ukr.net

${ }^{2}$ Department of Finance, Banking and Insurance, Tavria State Agrotechnological University.

E-mail: yatsuh@ukr.net 


\section{Statement of a problem}

Developed business sector forms the export potential and income tax revenue. There are creating jobs thanks to companies, as well as foundations of the country's financial safety are laid. Any changes in the economy cannot occur without affecting the enterprise. Moreover, the reforms and structural changes designed to create conditions for attracting investments, growth of business activity, and increase the profitability of enterprises. However, the number of unprofitable enterprises in the economy remains significant, despite numerous reforms and changes. Conservation of a problem of a large amount of loss-making enterprises is especially important in comparison with other countries. For example, in the Russian Federation, the share of unprofitable enterprises did not exceed $33-36 \%$ in 2014-2016.

Research of the current state of the economy gives grounds to assert that the entrepreneurial sector of Ukraine remains sensitive to a variety of adverse internal and external factors (Hanzyuk, 2016). The objective reaction for companies is to reduce production and sales volumes, optimization of personnel structure. Business leaves the market, and most importantly - has negative financial performance.

The objective of this article is the investigation of financial results of Ukrainian enterprises and identification of the main problems that cause unprofitable, and then offer ways to overcome the financial crisis.

\section{The research method}

Research materials: analyses, calculations, and articles formed the basis for writing this article. The scientific method became correlation analysis, comparative analysis, a method of description, interpretation of statistical data, a method of observation.

\section{Problem-solving}

\subsection{The financial results of enterprises in Ukraine} and the main reason for their loss

Since 2014, Ukraine is actively pursuing reforms on the path to European integration, discarding the inefficient control mechanisms. The priority remains the establishment of mechanisms for fair market relations, as well as ensuring a socially oriented economy of the vector. A sharp change in the direction of development is displayed on the macroeconomic indicators almost instantaneously. In particular, the national currency depreciated by more than 3 times. The consumer price index amounted to $124.9 \%$ in 2014 and $143.3 \%$ in 2015 . The fall of GDP amounted to $-28.1 \%$ in 2014 (in million dollars) in 2014 and $-31.3 \%$ (in millions of dollars) in 2015.
These changes are displayed on the activity of enterprises of Ukraine. The main problems of enterprises should be called:

- Decrease in domestic purchasing power of the population;

- Instability of national financial system and, as a result, limited access to financial resources. Since 2014, Ukrainian business has lost about $25 \%$ of the capital, which has remained in insolvent banks;

- Decrease in investment attractiveness and, as a consequence, the outflow of financial investments of foreign partners;

- Abrupt cessation of business contacts with the markets of the Russian Federation, which takes about one-third in the Ukrainian export structure;

- Military aggression in Ukraine, which led to a loss of about $18 \%$ of the country's industrial potential;

- High level of shadow economy;

- Instability of tax legislation, the abolition of state support and tax relief programs;

- Poor asset structure, the presence of obsolete technology and worn-out fixed assets.

In addition, only $16.8 \%$ of enterprises in Ukraine engaged in innovative activity in 2013 (Grynko, Gviniashvili, 2015). On the other hand, technology is one of the main stimulants of the global market formation. Therefore, development of technology encourages the integration of markets (Obradovic, 2015). The statistical information allows analysing the current situation with the financial results of Ukrainian companies (Fig. 1).

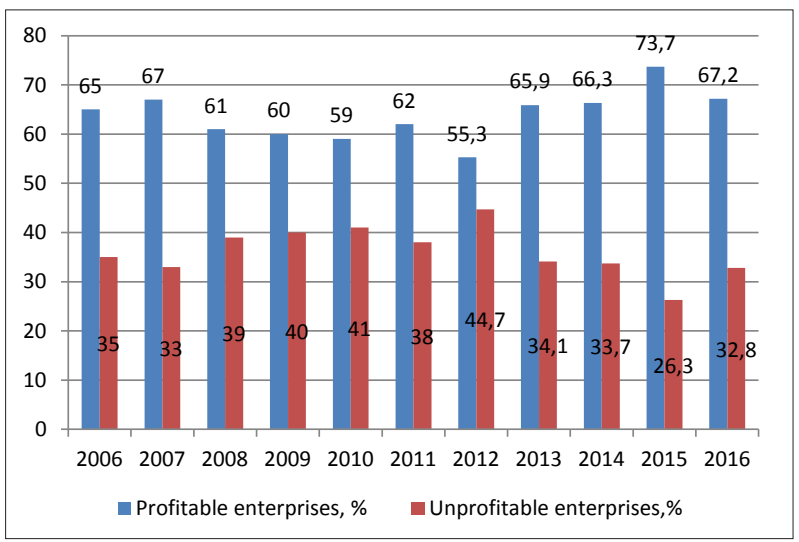

Fig. 1. Dynamics of profitable and unprofitable enterprises in Ukraine, \%

Source: built by the author based on (State Statistics Service of Ukraine, 2016)

From 2008 to 2012 there was a tendency of the growth of the share of unprofitable enterprises in the economy. The maximum value of this indicator amounted to $44.7 \%$ in 2012. In general, the number of companies with a negative financial result remained stable - about $33 \%$. At the end of 2015 and 2016 may judge the downward trend in the loss ratio in the Ukrainian economy. In 
particular, the share of unprofitable enterprises was minimal in $2015-26.3 \%$.

Representation of the Ukrainian companies will display more accurate the value of the financial result from operating activities (Fig. 2).

The figure shows the depth of the crisis in the economy. Despite the minimal share of unprofitable enterprises for the entire period of the study (26.3\%), in 2015 their financial performance ( 815.4 billion UAH of loss) resulted in a negative value of the indicator for the entire economy of Ukraine: -340.1 billion UAH. Losses of companies in 2014 were even greater: -523.6 billion UAH for all subjects. For loss-making enterprises (33.7\%), there is 858.1 billion UAH of loss.

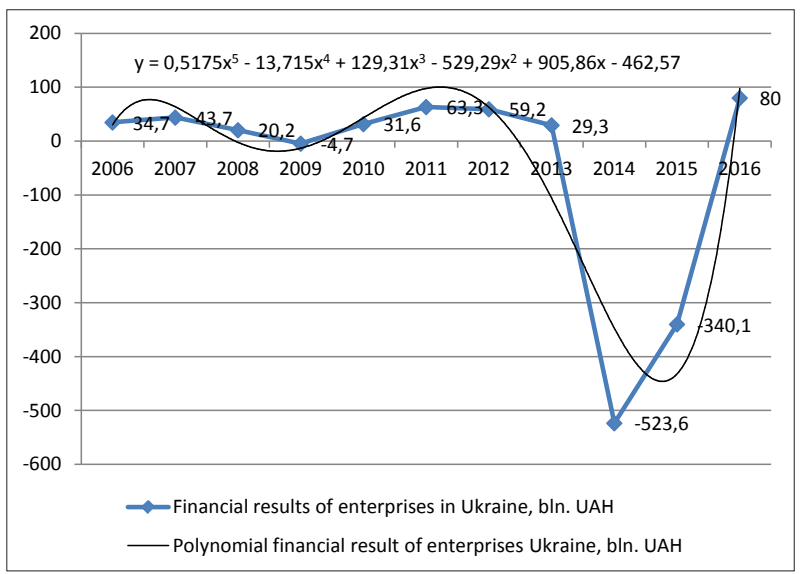

Fig. 2. Dynamics of financial results of enterprises in Ukraine, billion UAH

Source: built by the authors based on (State Statistics Service of Ukraine, 2016)

For economic activity situation is mixed. The smallest share of unprofitable enterprises in Ukraine in 2016 was observed in agriculture $-12.4 \%$ of total amount of enterprises in the industry. However, this situation is explained by preferential tax treatment (single tax, in which an object enters the land for agricultural purposes and the availability of tax relief VAT). However, the financial result of unprofitable agricultural enterprises has led to a negative result overall industry: -214 million UAH in 2016.

The most profitable sectors of the economy Ukraine in 2016 were a branch of financial and insurance activities (40.9 billion UAH) and professional, scientific and technical activities (32.1 billion UAH respectively). Financial stabilization indicates overcome the peak of the financial crisis and lay the foundations for further growth. But there are still a great number of unprofitable and insolvent companies - about $32 \%$.

\subsection{Financial and economic characteristics of the} development of enterprises

Data on the financial results of the companies may be incorrect due to the high shadowing of the economy. There is an increase of the illegal black market and the redistribution of the real economy. Periodically revealed violations in the field of nature and the extraction of valuable minerals (Kaszuba, 2015). In fact, the outflow of funds in the informal sector occurs in any of the sectors of the economy. At the same time, the revenue part of the budget is suffering because of the informal sector enterprises activity is hidden from the state and does not simulate the development of the economy (Osadcha, 2016).

A great number of companies do not even put profit as a primary objective. Often, the finished products are sold through a well-developed network of intermediaries, which leads to leaching of capital to offshore zones. A number of companies created for the control of resources and markets. This ensures the preservation of monopoly position in the industry.

In the field of agriculture, which used the indirect support of the state in the field of tax regulation for a long time, subjects did not carry out a revaluation of assets. This leads to a distortion of data on income and the number of profitable enterprises. However, the situation may change due to the increased tax burden on agricultural producers.

A strong influence on the development of business in Ukraine has professional management, as well as willingness for innovations. The tendency to diversify production and to attract financial resources, the application of current approaches to the business organization, as well as the presence of a sound financial strategy for specific enterprises ensure the effectiveness of the overall economy.

Giving a description of the business, we should take into account the objective realities of economic development. This is a condition, which is objectively facing any enterprise. Consider the impact of inflation on the performance of enterprises (Fig. 3).

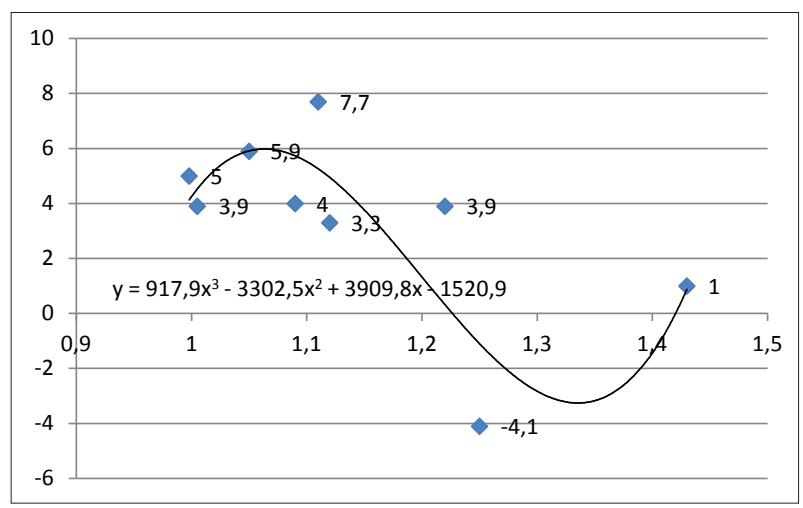

Fig. 3. Dependence of the profitability of operational activity on inflation

Source: built by the authors based on (State Statistics Service of Ukraine, 2016; Solyanik, 2013)

It can be noted that the increase in inflation leads to lower profitability. However, in the short term, there is an increase in profitability by increasing the value of 
the finished product (Solyanik, 2013). Note that sell products at a price that reflects the reality are not always obtained. In addition, companies face an increase in raw material costs and materials. Only the professionalism of managers will depend on the timeliness and adequacy of the increase in the price of finished products.

Study of dynamics of industrial products production in Ukraine (Fig. 4) gives an indication of the volatility of this indicator. The wave nature of the production volume is often explained by the volatile external markets. A logical extension of the recession of 20112013 has become a deep crisis and the decline in industrial production in 2014 and 2015 when the index of industrial production amounted to only $87 \%$. In 2016, the figure for the first time from 2011 exceeded $100 \%(102.1 \%)$. However, the increase in production is connected with the low base of comparison primarily.

Among the salient trends of enterprises in Ukraine, we should mention the tendency of falling net profit enterprises to reduce product sales index while capital growth (Table 1). For example, such a situation is observed in 2012, 2013, and 2014 respectively. This indicates poor quality of management because the increase in cash flows from revenues did not cause the accumulation of profit. Instead, the funds allocated to the increment of the capital of the company.

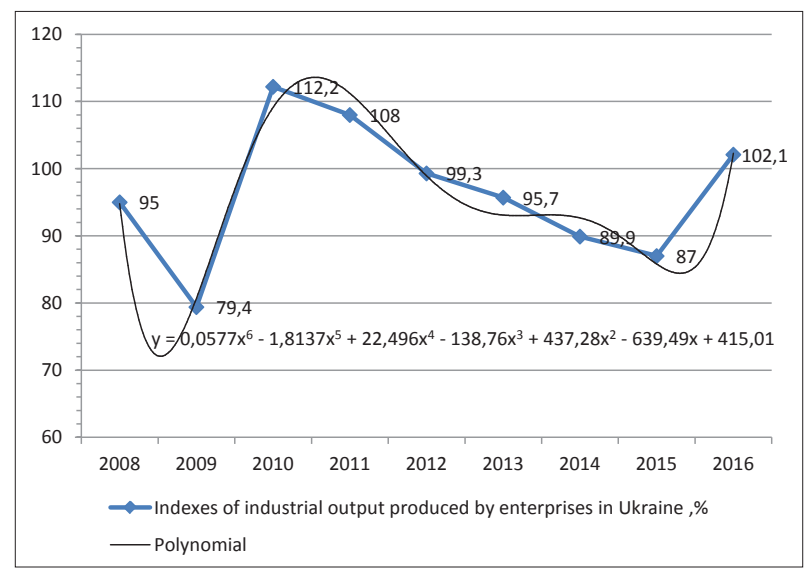

Fig. 4. Dynamics of indexes of industrial output produced by enterprises in Ukraine, \%

Source: built by the authors based on (State Statistics Service of Ukraine, 2016)

As a result, the capital structure is unsatisfactory. Enterprises overcharged interest on loans or have significant increases or penalties payable. This situation makes the achievement of innovative development and responsible coping strategies in the industry almost impossible.

Such trends are due to technological backwardness industrial complex of Ukraine in comparison with developed countries of Europe and the world. Also inadequate is the technology, the structure of production, and the quality of the resulting product. For example, in the metallurgical sector in total output, the share of continuous casting of steel was 53.5\% in 2011. Instead of developed countries on this parameter is much higher - 93\% (Solyanik, 2013).

The complexity of managing and adverse financial and economic environment cause pressure on the solvency of companies. For companies, it becomes more difficult to fulfil the obligations in time, while gradually increasing the amount of accounts receivable and current liabilities (Fig. 5). By the way, in terms of inflation and a significant number of bankrupt enterprises counterparty significant portion of accounts receivable becomes irredeemable.

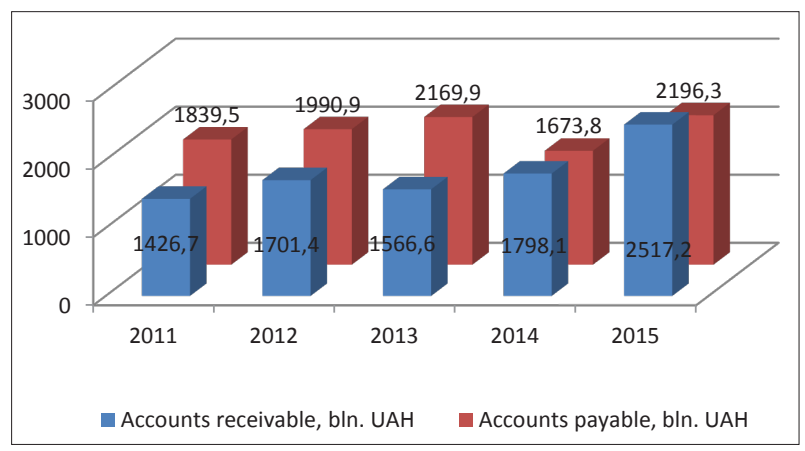

Fig. 5. Dynamics of accounts receivable and accounts payable of enterprises in Ukraine, billion UAH

Source: built by the authors based on (State Statistics Service of Ukraine, 2016)

In 2014 and 2015, there was an excess of receivables over payables enterprises of Ukraine to 124,3 billion UAH and 320,9 billion UAH respectively. Companies were experiencing solvency problems due to unreliable customers and clients. Performing current liabilities becomes difficult because companies reduced liquidity due to the high receivables.

The means determined by the cognitive hierarchical model of destructive factors of influence on the financial security of enterprises (Fig. 6) outlines the degree of action of factors of varied nature. Levels are from

Table 1

Dynamics of indices of profits, sales, and capital of enterprises in Ukraine in 2011-2015

\begin{tabular}{|l|c|c|c|c|c|}
\hline \multicolumn{1}{|c|}{ Indexes } & 2011 & 2012 & 2013 & 2014 & 2015 \\
\hline Index of net profit & 396,4 & 63,7 & $-65,0$ & $|2588,0|$ & $|63,3|$ \\
\hline Index of sales of products & 118,6 & 105,3 & 96,4 & 103,0 & 123,7 \\
\hline Index of capital of enterprises & 114,7 & 116,8 & 98,6 & 112,2 & 111,3 \\
\hline
\end{tabular}

Source: built by the authors based on (State Statistics Service of Ukraine, 2016) 


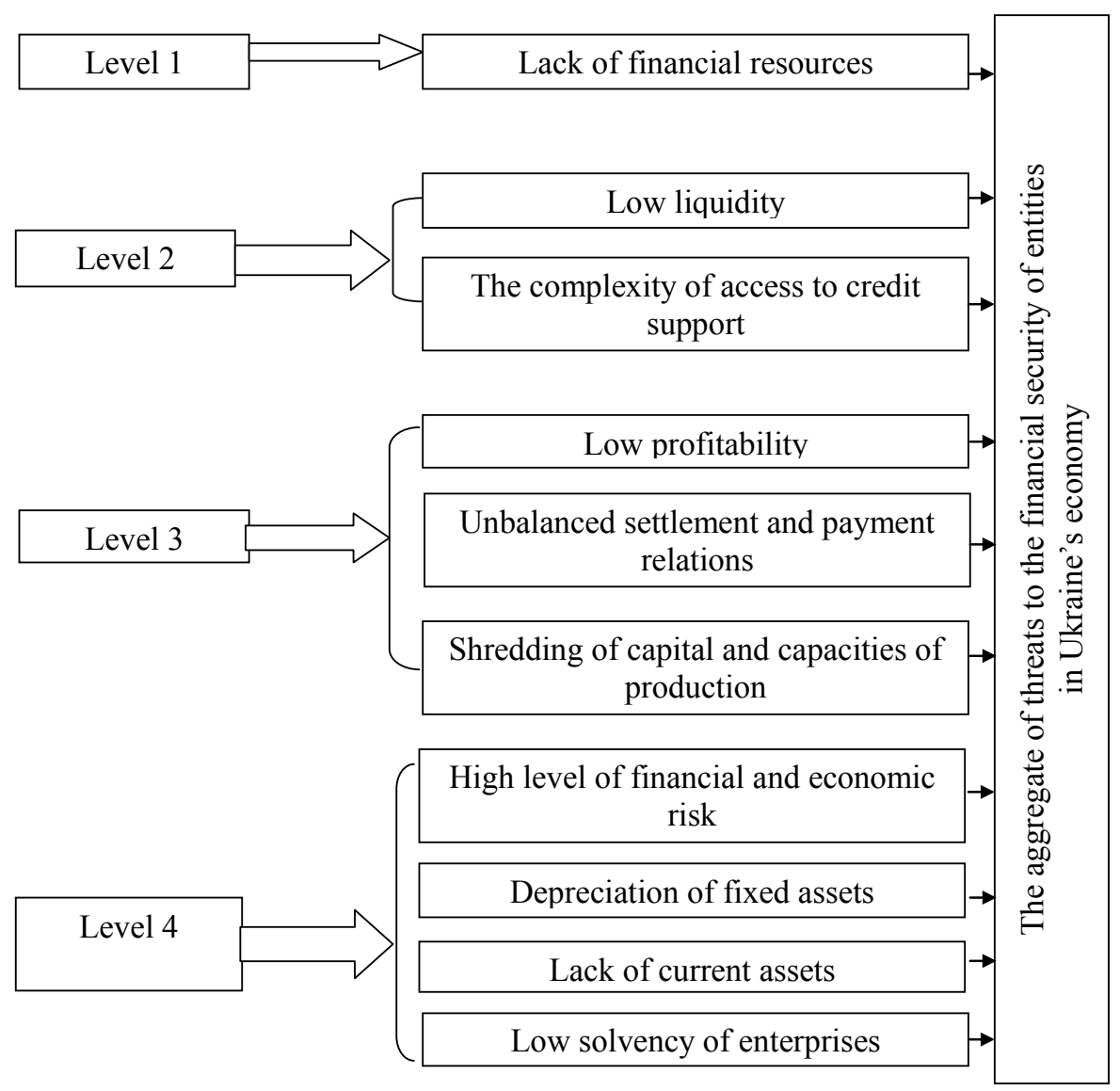

Fig. 6. Hierarchical model of destructive factors of influence on financial results and financial security of enterprises of Ukraine

Source: the author's development

the most significant (level 1) to the least influential (level 4). As a result, it was discovered that the lack of financial resources for enterprises has the most adverse effects.

Profits become the basis for further development, forming reserves and own financial resources of the enterprise. In this case, the shortage of own resources, along with the complexity of attracting additional sources of funding, lead to further aggravation of the financial crisis in the enterprise.

\section{Discussion}

At this stage of development, business sector of Ukraine is in a difficult position. The economy is characterized by a large share of unprofitable enterprises (Fig. 1), large losses (Fig. 2), and the low efficiency (Fig. 3 ). Companies of all sectors, sizes, and ownership are forced to operate under a redistribution of markets, the rapid devaluation of the national currency, and the growth of non-payment. During the military aggression and falling real incomes of the population, the government has other priorities, hence the collapse of government support programs.
The study (Table 1) shows the inefficiency of the distribution of received cash proceeds by enterprises. It is explained by a large amount of borrowed funds, high cost and large size of the tax burden. As a result, companies are not able to invest in the development of its own advanced technologies and have to resort to a "survival" strategy.

However, the existing capacity and potentially capacious internal market provide a hope for restoring profitable activity. Economy's restore performance conditions fixed assets through investment or aimed state support. At the same time, businesses need to diversify markets and to ensure the competitiveness and quality of the finished product.

\section{Conclusion}

A significant number of loss-making enterprises and a negative financial result are the problems of the national economy. Business is rapidly trying to adapt to the new realities of management, as well as actively seeking new markets for finished products. In such circumstances, to the forefront of management's ability to timely find and identify possible threats in a constantly changing 
environment. Research has shown that successful and profitable will be the company that takes into account in its work ongoing reform processes, inflation, and the changing role of the state.

The study demonstrated that to ensure the solvency, it is necessary to prevent the increase in accounts receivable and cooperate only with reputable customers and buyers. Indexing on the inflation the debt level of protection against the depreciation of assets that are invested in products delivered or services rendered.

Further research should be focused on the creation of a system of crisis management and risk management.
Such enterprise management segments are designed to provide financial security for the activities, the formation of positive financial results, and timely neutralization of threats of any type.

\section{Acknowledgement}

This paper was supported by Tavria State Agrotechnological University's scientific program No. 0116U002742 "Developing scientific and methodological foundations of financial basis for the socio-economic development of rural areas in terms of increasing the autonomy of regions"

\section{References:}

Abotsi, A., Dake, G., Agyepong, R. (2014) Factors Influencing Risk Management Decision of Small and Medium Scale Enterprises in Ghana. Contemporary economics, Volume 8 Issue 4, pp. 397-414. DOI:10.5709/ce.18979254.153.

Adonin, S. (2015) Rozshyrennja bazy opodatkuvannja jak meta podatkovogo kontrolju [Expansion of base of taxation as the aim of tax control]. Economic analysis, Volume 21 №1, pp. 146-150.

Berest, M. (2012) Statystychnyj analiz procesiv bankrutstva v Ukraini [Statistical analysis of the bankruptcy process in Ukraine]. BusinessInform, Volume № 6, pp. 089-092.

Grynko, T., Gviniashvili, T. (2015) Organizational Changes at the Enterprise within the Context of Its Innovative Development / Economic Annals-XXI, Volume № 1-2(2), pp. 51-54.

Hanzyuk, C. (2016) Finansova kryza na pidpryjemstvah Ukrainy [Financial crisis in Ukraine companies]. Young Scientist, Volume № 3 (30), pp. 049-052.

Kashuba, O. (2015) Pidpryjemnyctvo v Ukraini: problemy ta perspektyvy rozvytku [Entrepreneurship in Ukraine: problems and prospects of development]. Economy and State, Volume №6, pp. 103-106.

Kovalchuk, N. (2016) Antykryzovyj finansovyj menedzhment jak osnova upravlinnja finansamy vitchyznjanyh pidpryjemstv [Anti-crisis financial management as a basis for financial management of domestic enterprises]. Economy and Society, Volume №3, pp. 203-208.

Kozak, L.S., Danchuk, M.V. (2016) Evolution of enterprise risk management under current conditions of economic development: from fragmented to integrated. Actual Problems Of Economics, Volume №4 (178), pp. 23-30.

Kravchenko, O. (2006) Vyznachennja chynnykiv zbytkovoi dijalnosti promyslovyh pidpryjemstv v Ukraini [Determining factors of unprofitable activity of industrial enterprises in Ukraine]. Papers of the Odessa Polytechnic University, Volume №2 (26), pp. 256-260.

Moskalenko, N., Romanenko, O., Oliinyk, T. (2015) Approaches to enterprises' financial and economic security management. Economic Annals-XXI, Volume 7-8 (1), pp. 054-057. DOI:10.21003/ea

Neskorodyeva, I. (2011) Suchasni tendencii bankrutstva pidpryjemstv v Ukraini ta shljahy ih vyrishennja [Current trends of bankruptcy of the enterprise in Ukraine and solutions]. Journal of economy and transport industry, Volume № 36, pp. 187-193.

Obradovic, D., Ebersold, Z., Obradovic, D. (2015) The role of technology strategy in competitiveness increasing. Economic Annals-XXI, Volume №1-2 (1), pp. 32-35.

Osadcha, G.; Stepaniuc,A. (2016)Zbytkovist pidpryjemstvjakforma projavu tinizacii ekonomiky [Unprofitableness of companies as a form of manifestation of the «shadow» economy]. Global and national economic problems, Volume № 11, pp. 886-890.

Schieg, M. (2006) Risk management in construction project management. Journal of Business Economics and Management, Volume №7, pp. 077-083.

Solyanik, L. (2013) Vid zbytkovosti do prybutkovosti: kljuchovi faktory uspihu vitchyznjanyh pidpryjemtv [From losses to profitability: key success factors of national enterprises]. Economic Journal of National Mining University, Volume (Issue) №3, pp. 073-081.

State Statistics Service of Ukraine (2016) Statistical information: business activities. [online] www.ukrstat.gov.ua. Retrieved from: URL http://www.ukrstat.gov.ua (Accessed 27.12.2017)

Vasylyshyn, T. (2013) Analysis of the modern condition of machine-building industry of Ukraine and determination of the main development problems. Galician Economic Journal, Volume № 4 (43), pp. 010-020.

Zhivko, Z. (2013) Upravlinnja ekonomichnoju bezpekoju agrarnogo pidpryjemstva [Management of economic security of agricultural enterprises]. Scientific Bulletin of Lviv National University of Veterinary Medicine and Biotechnology named. S.Z. Gzhytsky, Volume 15 № 2 (56), pp. 081-089. 